\title{
Investigation of Thermal Comfort in University Offices: The Case of the Bingöl University
}

\author{
Gonca Özer Yaman', Fatma Kürüm Varolgüneş",", Perihan Çulun ${ }^{2}$ \\ ${ }^{1}$ Department of Architecture, Faculty of Engineering and Architecture, Bingöl University, Bingöl, 12000, Turkey \\ ${ }^{2}$ Department of Mechanical Engineering, Faculty of Engineering and Architecture, Bingöl University, Bingöl, 12000, Turkey
}

Received January 12, 2021; Revised July 23, 2021; Accepted October 20, 2021

\section{Cite This Paper in the following Citation Styles}

(a): [1] Gonca Özer Yaman, Fatma Kürüm Varolgüneş, Perihan Çulun, "Investigation of Thermal Comfort in University Offices: The Case of the Bingöl University," Civil Engineering and Architecture, Vol. 9, No. 7, pp. 2441 2451, 2021. DOI: 10.13189/cea.2021.090729.

(b): Gonca Özer Yaman, Fatma Kürüm Varolgüneş, Perihan Çulun (2021). Investigation of Thermal Comfort in University Offices: The Case of the Bingöl University. Civil Engineering and Architecture, 9(7), 2441 - 2451. DOI: 10.13189/cea.2021.090729.

Copyright $\bigcirc 2021$ by authors, all rights reserved. Authors agree that this article remains permanently open access under the terms of the Creative Commons Attribution License 4.0 International License

\begin{abstract}
Thermal comfort and indoor air conditions affect the mental and physical performance of users. People spend most of their time indoors. The thermal comfort conditions of these places directly affect the performance of individuals. Today, there are few examples of interior spaces with suitable conditions in terms of thermal comfort. Academician work offices in university buildings are also places where academics spend a long time. In this context, it is important to investigate and examine the thermal comfort conditions of these places and to put forward suggestions for improvement. For this reason, in this study, examinations were made in the offices of academicians in the Faculty of Engineering and Architecture. Within the scope of the study, 9 (nine) offices orientated in different directions were determined. Temperature, humidity, air movement and radiant temperature values were measured in the offices during January-February 2021, which is the period when the spaces in these offices should be heated. Measurements were made using a multi-functional air conditioner. The data obtained as a result of the measurements were interpreted according to the ASHRAE standard 55 and ISO 7730 limit values. It has been understood that the mean comfort temperature value found in all the offices of the university staff is in compliance with ASHRAE standards and the relative humidity of the air is insufficient.
\end{abstract}

Keywords Thermal Comfort, Air Flow Rate, Relative
Humidity, Experimental Research, University Offices, Bingöl

\section{Introduction}

People spend most of their lives ( 90\%) indoors [1,2]. It is necessary to improve the living conditions indoors and to provide users with comfort for this reason. One of the important elements affecting user comfort in places is the thermal comfort conditions in the space [3,4]. Thermal comfort directly affects situations such as individuals' living healthier, being able to produce more effective work in the working environment, and feeling psychologically more comfortable [5]. Additionally, previous research has shown that indoor climatic conditions in offices have a significant impact on human performance. Therefore, comfortable and healthy indoor conditions should be considered as the most important goal in energy efficient buildings containing modern offices [6-8].

Thermal comfort is the ambient values with which users mentally feel comfortable according to ASHRAE-55 standards [9]. In other words, thermal comfort is defined as the expression of satisfaction with the thermal environment in people's minds $[10,11]$. Thermal comfort is a measure of the satisfaction or dissatisfaction of individuals feel when interacting with the thermal environment. It indicates 
whether individuals in a space are in particular comfort in terms of ambient conditions such as temperature, airflow rate, and humidity while continuing their activities. Olgyay [12] states that the relationship between heat and humidity conditions is a factor in the comfort area. Thermal comfort is not only dependent on ambient temperature and humidity, but also affected by other parameters. For example, the temperatures felt by people exposed to the same temperatures and humidity in the same place may be different. This situation reveals both the difficulty and the importance of determining thermal comfort conditions. Individuals begin to feel uncomfortable in a place and this may lead to a decrease in working performance, distress, and discomfort, especially in the working environment if thermal comfort conditions are inadequate in the place. The indoors must provide some conditions in order to provide thermal comfort. Some researchers divide the environmental variables affecting thermal comfort conditions into 4 groups (air temperature, mean radiant temperature, relative humidity, air velocity) and two personal variables (metabolic rate and clothing insulation) [13-20]:
- Air temperature
- Mean radiant temperature
- Relative humidity
- Air velocity

Brief descriptions of these parameters are as follows;

Air temperature is effective directly in convection heat loss and evaporation, and also effective indirectly in conduction heat loss because of the difference in surface temperature of objects in the space [21]. Two types of temperatures can be mentioned. The first is the temperature measured by the dry thermometer (which called the actual temperature), and the second is the temperature people felt (which called wet bulb temperature). The heat index is the definition of the relationship between air temperature and humidity value of air [19]. The human body constantly exchanges heat with the environment it is in. The body loses heat when the temperature of the environment is lower than the temperature of the body. The body gains heat when the temperature of the current environment is higher than the body temperature. The metabolic activities occurring vary and discomfort occurs since body temperature will vary during this heat exchange [17].

Mean radiant temperature is the type of energy that reaches and is stored on heat-storing surfaces. It originates from sunlight or an object with a high temperature, such as a heater or oven. This type of heat increases the air temperature but heats up the solid surfaces in the space more quickly [21]. The radiant temperature occurring in space is closely related to the surfaces in the space [20]. It is often undesirable to gain this heat in an uncontrolled way. However, it is possible to control this situation with some architectural solutions.

Another important factor affecting comfort conditions is humidity. The amount of water vapour in the air refers to humidity. Humidity in the air is examined under two headings as absolute and relative humidity. Absolute humidity refers to the amount of water vapour contained in the unit air. Relative humidity can be expressed as the maximum rate of water vapour the air can carry at related temperature. The increase in this rate causes a feeling of depression and may result in performance decreases while the decrease in the humidity in the spaces makes our body feel cold. Therefore, the humidity in a space is an important climate element that should be controlled in terms of ensuring thermal comfort. The most accepted relative humidity range is $30 \%$ and $70 \%$ and $50 \%$ is the ideal value according to the study of Zhang et al. [22]. Environments with high humidity contain large amounts of water vapour. Less sweat will evaporate when the humidity is $80 \%$ or more when the air temperature is high. The most important cause of heat loss from humans' body is the evaporation of sweat [10]. High humidity causes people to feel warmer than low humidity in hot weather. If the air has high humidity, the evaporation rate of sweat decreases. Cold weather conditions always have low humidity and thus evaporation rate of sweat do not constitute an important factor in cold weather [22].

One of the important climate elements affecting thermal comfort conditions is the air velocity. In addition to temperature and humidity factors, air velocity has a great effect on thermal comfort. It is possible to provide the same comfort conditions with the air velocity rate in two environments with different humidity and temperature values. Air velocity is caused by the movement of air. Air moves from high pressure to low pressure. High pressure occurs in cases where the temperature is high and low pressure occurs in cases where the temperature is low; therefore, an air velocity occurs from hot environments to cold environments. The air velocity increases as the temperature difference between the two environments increases [23]. People feel cooler when the air velocity is higher in the equivalent comfort environment. In low ambient temperatures, if the air velocity is above 0.3-0.5 $\mathrm{m} / \mathrm{s}$, heat stress occurs on peoples [24]. By increasing the ambient air velocity rate by $1 \mathrm{~m} / \mathrm{s}$, the ambient temperature can be reduced up to $2.7^{\circ} \mathrm{C}$ [25-27]. Therefore, natural ventilation methods can be used by using air velocity limits in the spaces. Ambient temperature values can be reduced with the help of a fan instead of mechanical ventilation in this way. The change of ambient air velocity constitutes an important parameter that can be used at the point of energy saving.

Productivity and work efficiency increase significantly in places where the user feels comfortable. Therefore, thermal comfort is very important, especially in office spaces. Academicians' study offices in university structures are also places where academicians work and spend long times. Therefore, it is very important to investigate thermal comfort in these spaces and to make suggestions for improvement. In this study, it is aimed to determine the 
thermal comfort conditions in the academicians' offices at Bingöl University. In this context, 9 (nine) offices were determined and measurements were made in these offices. While determining the offices, 'different orientation, size of the space, available equipment, ratio of opaque and transparent surfaces, number of users' characteristics must be taken into account. The measurements were made in January-February, which is the heating period of the buildings. The measurement results were compared with the evaluations in the ASHRAE-55 and ISO 7730 standards. As a result of the study, the relationship between 'the different orientation, the size of the space, the available equipment, the ratio of opaque and transparent surfaces, the number of users' characteristics of the offices and the thermal comfort conditions has been revealed.

\section{Materials and Methods}

In the study, thermal comfort parameters of Bingöl University Faculty of Engineering and Architecture work offices were measured. The study was conducted with two methods, which were field research and experimental measurements. The climatic/environmental situation and structure were examined on-site and the information was compiled in the field research. A multi-purpose air conditioning device and airflow rate-measuring device were used for experimental measurements. Infrared non-contact thermometer was used for wall temperatures to measure radiation temperature of offices. The measured parameters and the devices used are shown in Table 1.

Measurements were made especially in January-February considering that Bingöl province is in the cold climate region. 10.00-12.00 and 13.00-16.00 hours determined as working hours due to the Covid-19 outbreak in the period when the measurements were made. Measurements were taken from a point in the centre of office spaces and from a height of approximately 1 meter from the ground. Windows and doors were kept closed during measurements. The radiation temperature of a space is also related to the surrounding wall temperatures calculated with Equation 1 [28].

$$
T_{r}=\frac{0.08\left(T_{f}-T_{c}\right)+0.23\left(T_{R}-T_{l}\right)+0.35\left(T_{\mathrm{F}}-T_{b}\right)}{2(0.08+0.23+0.35)}
$$

Table 1. Measured parameters and Instruments used (edited by authors)

\begin{tabular}{|c|c|c|c|}
\hline Parameters & Instrument & Range & Accuracy \\
\hline Outdoor Temp. & Testo $480 \mathrm{CMI}$ & 0 to $60{ }^{\circ} \mathrm{C}$ & \pm 0.5 \\
\hline Comfort Temp. & Testo $480 \mathrm{CMI}$ & 0 to $60{ }^{\circ} \mathrm{C}$ & \pm 0.5 \\
\hline Relative Humidity (rH) & Testo 480 CMI & 0 to $100 \%$ & $\pm(1.0 \% \mathrm{rH}+0.7 \%$ Reading $)$ \\
\hline Air flow rate & Hot Wire Anemometer DT8880 & 0.1 to $25.0 \mathrm{~m} / \mathrm{s}$ & $\pm 5 \% \pm 0.1 \mathrm{~m} / \mathrm{s}$ \\
\hline Mean radiant temperature & $\begin{array}{c}\text { Cool-Us CU-IT InfraRed } \\
\text { Thermometer }\end{array}$ & 0 to $50{ }^{\circ} \mathrm{C}$ & $\pm 0.4{ }^{\circ} \mathrm{C}$ \\
\hline
\end{tabular}




\section{Results and Discussions}

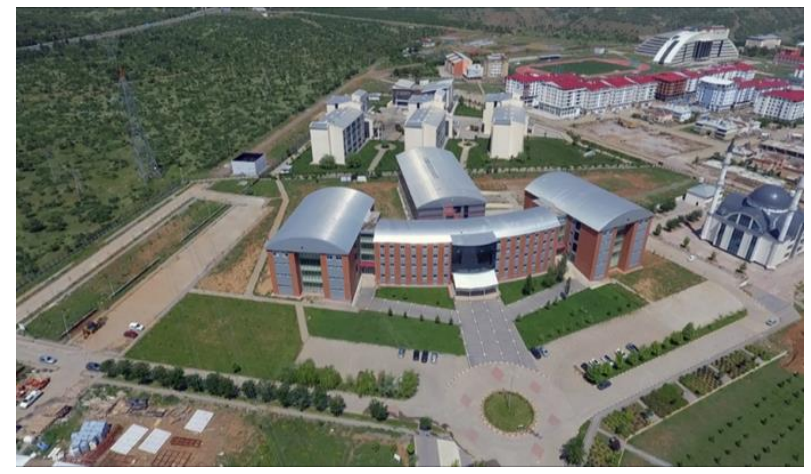

Figure 1. Overview of Bingöl University Faculty of Engineering and Architecture building

(Available at:

http://mmf.bingol.edu.tr/mansetler/muhendislik-mimarlik-fakultesi-1/)

This study was carried out in the academic study offices of the Faculty of Engineering and Architecture of Bingöl University. Bingöl University is within the borders of Bingöl Province. Bingöl Province is located at $41^{\circ} 20^{\prime}$ and $39^{\circ} 56^{\prime}$ east longitudes; $39^{\circ} 31^{\prime}$ and $36^{\circ} 28^{\prime}$ north latitudes in the Upper Euphrates Division of the Eastern Anatolia Region. Bingöl province is in a position where continental-temperate climate characteristics prevail according to Köppen-Trewartha climate classification due to its geographical location. It is cold and snowy in winter, while summer is generally warm and relatively short. It is seen that the maximum temperature exceeds $42^{\circ} \mathrm{C}$ whereas the minimum temperature in the region has decreased to $-25.1^{\circ} \mathrm{C}$ in the last two decades [29]. Such a wide fluctuation of the dry bulb temperature significantly affects the comfort conditions of indoor spaces [30]. Examining the educational structures that perform their functions through natural ventilation in terms of indoor comfort conditions will provide important results considering related climatic conditions. The faculty building where the measurements are made is located within the campus of Bingöl University. The faculty structure has a main building (Block A) built on campus in 2010 and an additional building (Block B) built in 2014. Block A has a curved shape and it is located parallel to the northeast (NE)-southwest (SW) direction. Block B was designed in perpendicular to block A, located parallel to the North West (NW) - South East (SE) direction with a rectangular shape (Figure 1).

Transparent surfaces on the exterior of both blocks consist of heat-insulated silicone curtain wall, and opaque surfaces consist of heat-insulated composite coating system. The building is heated by a central natural gas heating system. While no additional heating system is used in academicians' offices in winter, it has been observed that there is a need for the use of fans in some rooms in summer. The annex building consists of four normal floors with one basement and one ground floor. On the 4th floor of the annex building, there are academicians' offices facing the inner corridor (Figure 2a, Figure 2b). The ventilation and illumination of these rooms is provided by the polycarbonate skylight surface designed on the roof. However, in the on-site inspection, it was seen that the skylight was covered with a galvanized sheet roof covering. Passive ventilation of the rooms is provided by transom system windows in the rooms with exterior façades, and by doors and windows opening to the corridor in the rooms facing the interior corridor. The activity status of the users of the rooms is generally passive and semi-active.

\subsection{Data Analysis}

In this study, the thermal comfort conditions were investigated in the Bingöl University, Faculty of Engineering and Architecture offices. As mentioned before B block located parallel to the North West (NW) South East (SE) direction in Figure 1. Temperature, humidity, and dew point values of the offices directed to the northeast (NE) (offices 1, 2, and 3) were evaluated among themselves. Related data of the middle offices (offices 4, 5, 6 and 7) were evaluated among themselves. Finally, related data of offices facing the South West (SW) (offices 8 and 9) were evaluated among themselves. Also, monthly mean temperature, humidity, and dew point values were obtained. Table 2 shows the monthly mean temperature and humidity values of the measurements taken in January and February. As can be seen from the relevant table the mean temperature values of January and February were $24.7^{\circ} \mathrm{C}$ and $25.9^{\circ} \mathrm{C}$; the relative humidity values were $17.7 \%$ and $24.3 \%$. The mean temperature of the space in February is higher compared to the mean temperature in January. In addition, humidity values in February are slightly higher compared to January. According to ASHRAE standards, the ideal thermal comfort temperature should be between $20^{\circ} \mathrm{C}$ and $25.5^{\circ} \mathrm{C}$ and the relative humidity (RH) should be between $30 \%$ and $60 \%$. The relative humidity values were outside the ASHRAE (American Society of Heating) standards even though the monthly mean temperature values found were close to these standards. 

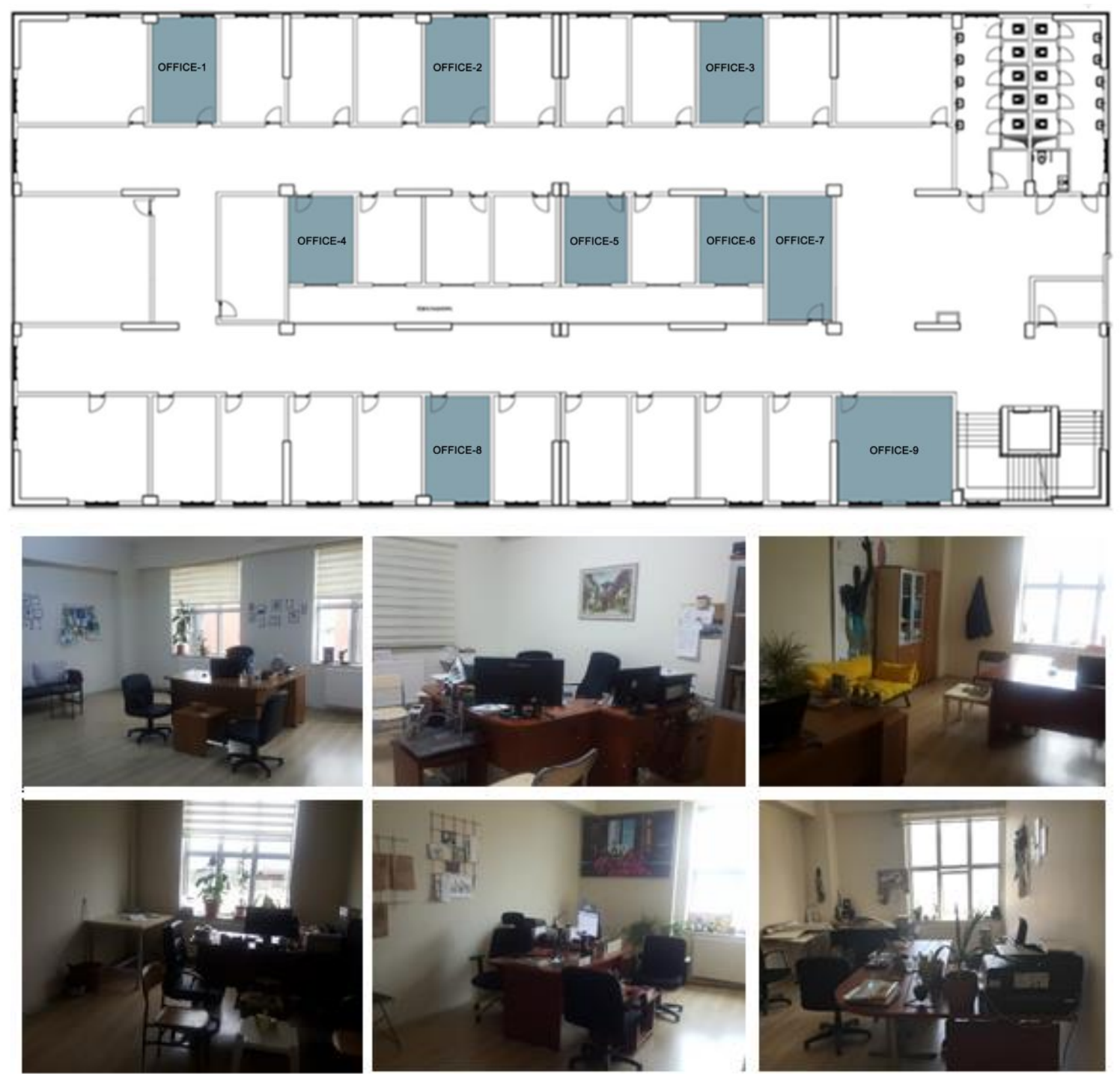

Figure 2. a. Floor plan of with offices where measurements are made (top) b. Examples of measurement offices (bottom) (Source: authors, 2021)

Table 2. Mean temperature and humidity values

\begin{tabular}{|c|c|c|c|c|c|c|}
\hline \multicolumn{4}{|c|}{ January } & \multicolumn{3}{c|}{ February } \\
\hline $\begin{array}{c}\text { Direction } \\
\text { (for offices) }\end{array}$ & Temperature $\left({ }^{\circ} \mathbf{C}\right)$ & $\begin{array}{c}\text { Relative humidity } \\
(\text { RH \%) }\end{array}$ & $\begin{array}{c}\text { Dew } \\
\text { point }\left({ }^{\circ} \mathbf{C}\right)\end{array}$ & Temperature $\left({ }^{\circ} \mathbf{C}\right)$ & $\begin{array}{c}\text { Relative humidity } \\
(\mathbf{R H} \%)\end{array}$ & Dew point $\left({ }^{\mathbf{}} \mathbf{C}\right)$ \\
\hline NE & 25,2 & 17,1 & $-1,4$ & 25,8 & 25,2 & 4,5 \\
\hline Middle & 24,2 & 19,0 & $-0,1$ & 26,0 & 22,3 & 2,8 \\
\hline SW & 24,8 & 17,1 & $-1,7$ & 26,0 & 25,3 & 4,6 \\
\hline Average & 24,7 & 17,7 & $-1,1$ & 25,9 & 24,3 & 4,0 \\
\hline
\end{tabular}




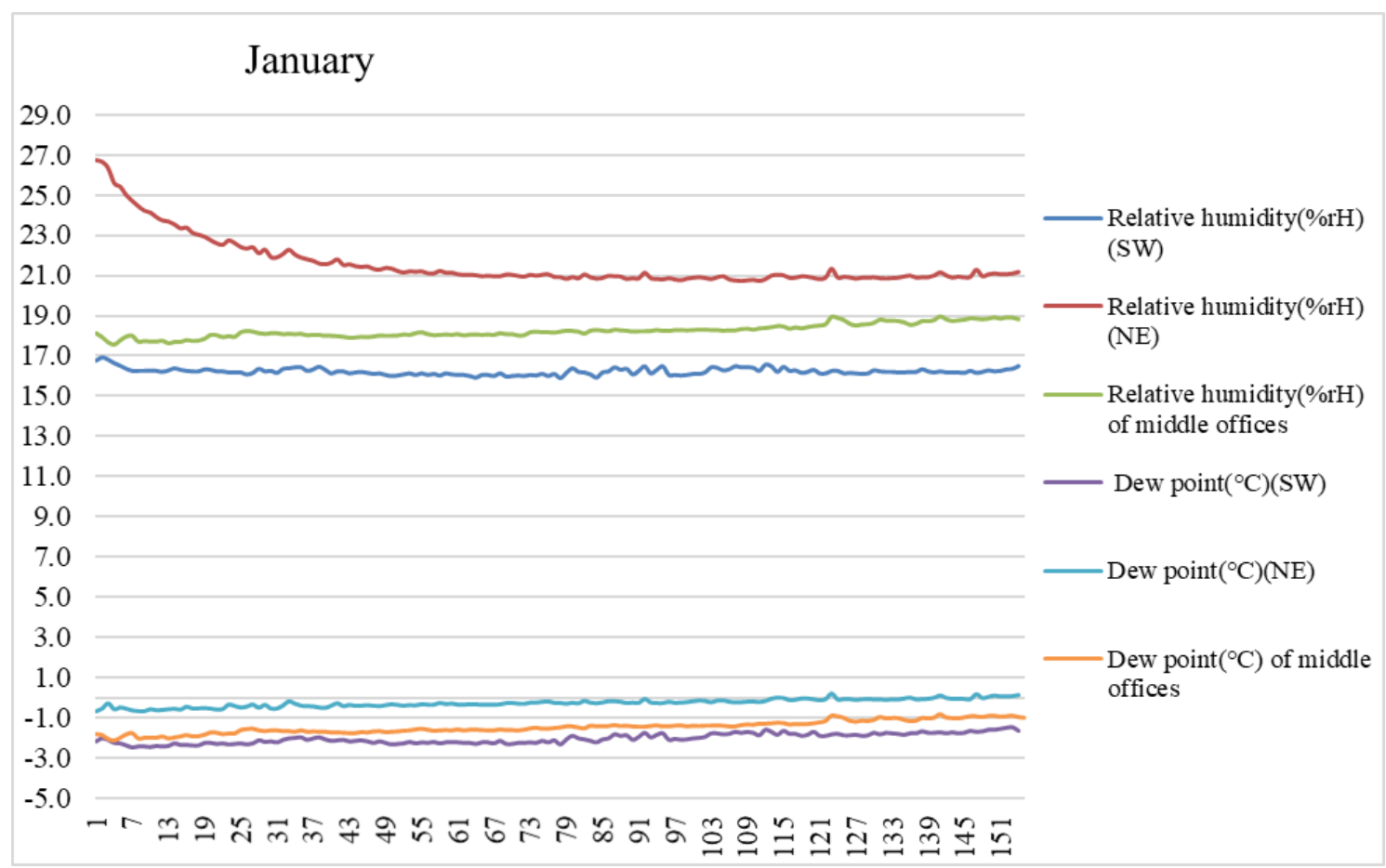

Figure 3. Relative humidity and dew point values in January

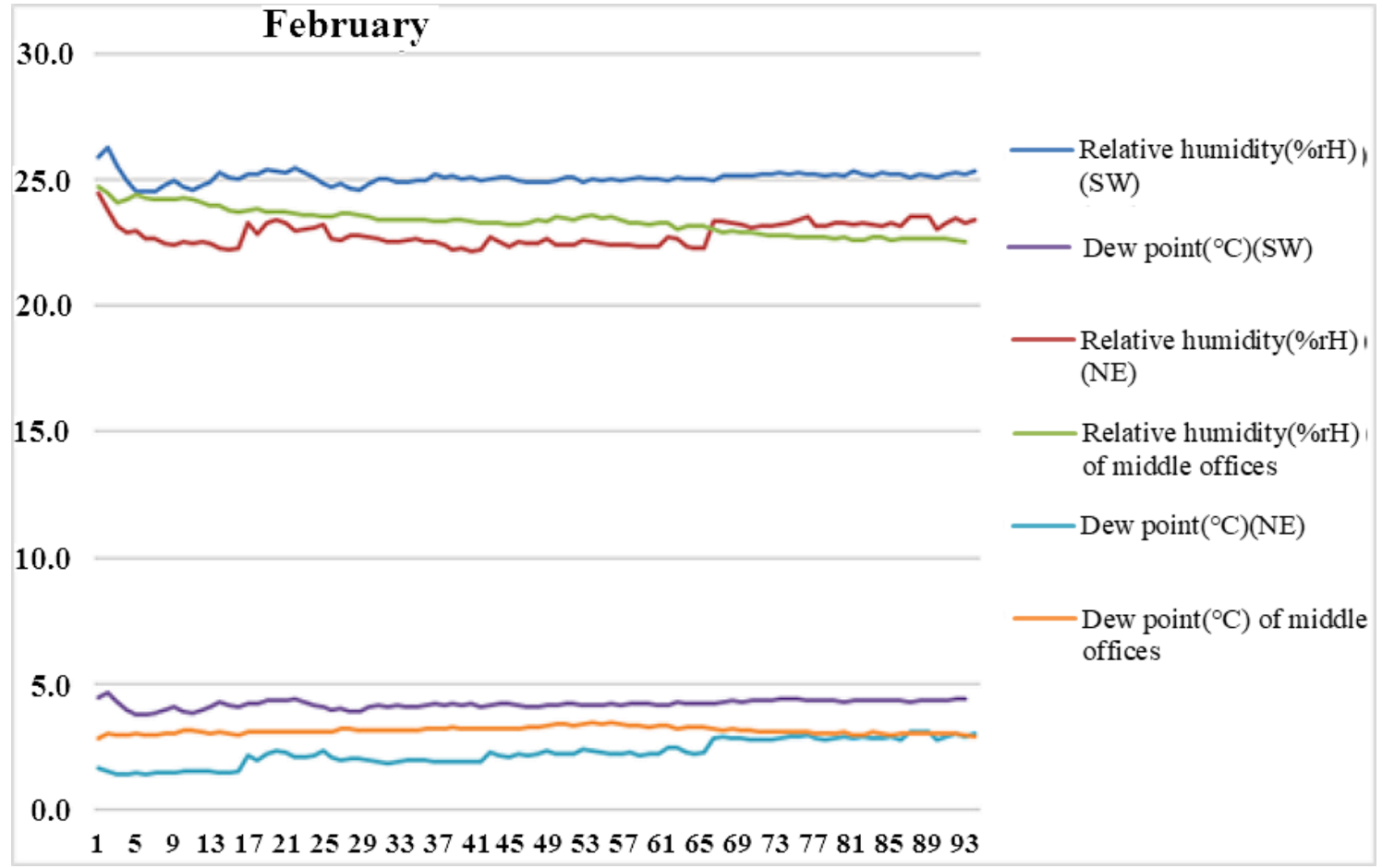

Figure 4. Relative humidity and dew point values in February

Relative humidity and dew point measurement values of the offices considered are shown in Figure 3 and Figure 4. Mean relative humidity (RH) and dew points of January for $\mathrm{SW}, \mathrm{NE}$, and middle offices are shown in Figure 3 and related dates of February are shown in Figure 4. Relative humidity value in January was between 16-25\% according to Figure 3. Humidity was highest in offices in the NE direction, lowest in offices in the SW direction, and between these two values in middle offices. January dew point values were in parallel with related humidity values. The highest dew point values were in NE offices, the lowest dew point values were in SW offices and middle offices dates were between both. The dew point values for all three-office categories were between 0 and $-5^{\circ} \mathrm{C}$.

The relative humidity value of February is between $23-25 \%$ according to Figure 4 . The highest humidity 
values were in SW offices, lowest in NE offices, between these values for middle offices. The dew point values of February showed similar characteristics to the humidity values. The highest dew point values were found in SW offices, the lowest dew point values were found in NE offices and middle offices were between both. Dew point values were between 0 and $+5^{\circ} \mathrm{C}$ in February.

It is understood from Figure 3 and 4 that relative humidity and dew point values are correlated with each other. Again, depending on the external environment conditions, the relative humidity value is either maximum or minimum in the SW direction or in the NE direction, while it takes occasional value in the offices in the middle corridor. However, the relative humidity values in January are lower compared to February. It is thought that the rains in February are effective in this situation. Because more precipitation was observed in February compared to January when the measurements were taken. This reveals that the relative humidity value is directly related to outdoor conditions. However, the mean relative humidity values in January and February appear to be below the ASHRAE standard relative humidity limit values. The mean relative humidity values in January were between $23-25 \%$ whereas the related values in February were between 16-25\%. The all relative humidity values were also below the limit values of $30-60 \%$. Figure 3 and Figure 4 show that January dew point values were between 0 and $-5^{\circ} \mathrm{C}$ and February values were between 0 and $+5^{\circ} \mathrm{C}$. According to the common result obtained from both figures, the dew point temperatures increased as the room temperature increased.

Mean comfort temperatures for January and February are provided in Figure 5 and Figure 6, respectively. The highest mean temperature value in the SW direction and the lowest mean temperature value in the NE direction were measured according to the January temperature values, as seen in Figure 5. This is a natural consequence of an increase in temperature in offices facing south and a decrease in temperature in offices facing north. The temperature value in the offices in the middle hallway was included between the two values. The mean temperature value in January for all offices was between $23-25^{\circ} \mathrm{C}$ and these values were within the standard value range.

Considering the February temperature values in Figure 6, generally the lowest average temperature value in $\mathrm{NE}$ direction has been obtained. The mean temperature value started with 23 and increased up to 25.5 in offices facing NE. Similarly, the mean temperature value starting with 24 in the middle hallway offices increased up to $26.5^{\circ} \mathrm{C}$. However, a mean comfort temperature of $25.5^{\circ} \mathrm{C}$ was observed in the SW direction.

The mean comfort temperature value for all offices in February was between $23-26.5^{\circ} \mathrm{C}$ and these values were within the standard value range. As can be seen from Figure 5 and Figure 6 comfort temperatures are within the standard values. Therefore, in this respect, it can be said that these places are comfortable in terms of comfort temperature in winter.

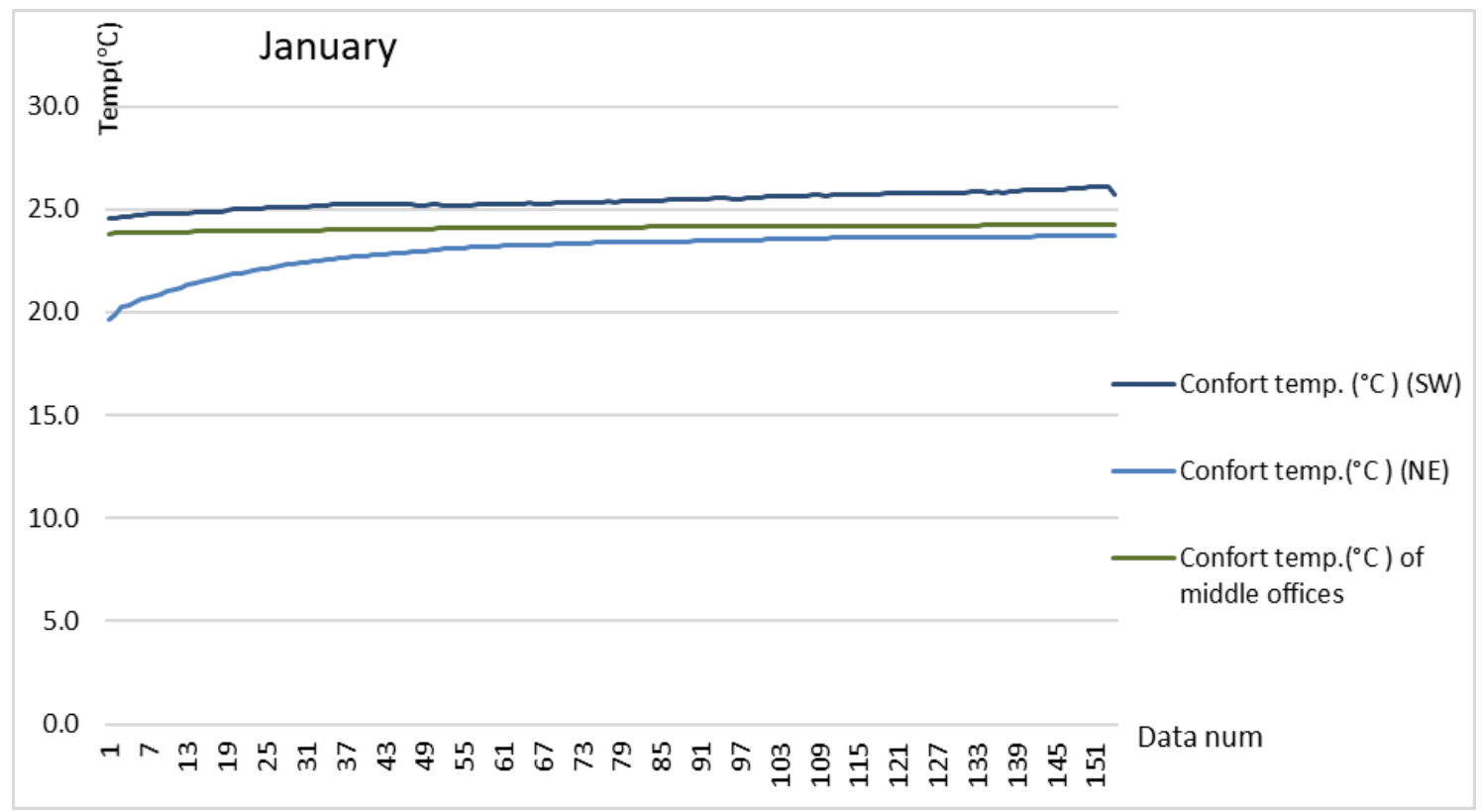

Figure 5. Mean comfort temperature values in January 


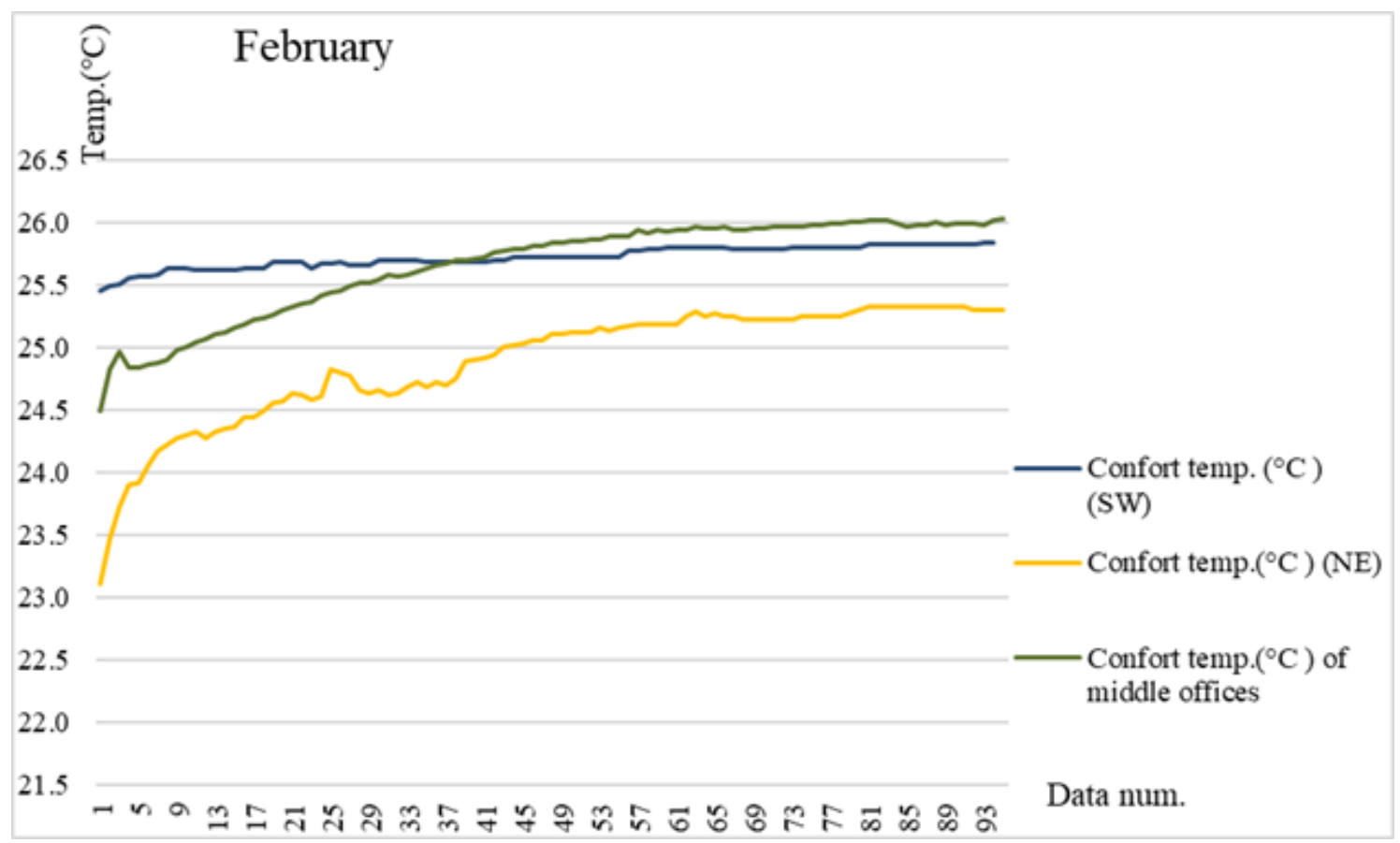

Figure 6. Mean comfort temperature values in February

Table 3. Mean radiation temperature $\left({ }^{\circ} \mathrm{C}\right)$

\begin{tabular}{|c|c|}
\hline Office number & Mean radiation temperature \\
\hline & NE Offices \\
\hline 1 & 22.6 \\
\hline 2 & 22.19 \\
\hline 3 & 21.53 \\
\hline & Middle offices \\
\hline 4 & 24.5 \\
\hline 5 & 25.16 \\
\hline 6 & 24.7 \\
\hline 7 & 25.5 \\
\hline & SW offices \\
\hline 8 & 22.5 \\
\hline 9 & 22.05 \\
\hline
\end{tabular}

The mean radiation temperature value, which is one of the basic thermal comfort parameters, is another important parameter in terms of thermal comfort. Calculated radiation temperature values of offices according to directions are given in Table 3. According to the results, the mean radiation temperature was lower in the facades offices compared to the middle offices. However, radiation temperatures were close to each other in offices facing NE and SW directions.

Another parameter of ambient comfort conditions is air velocity. Unaired environment occurs if the air velocity is lower than it should be. Working performance and efficiency decrease in unaired spaces.

On the other hand, the high air velocity causes the body to lose heat. Air velocity in indoors is known to be effective on skin temperature and heat loss [31]. Figure 5 shows the 7 -day mean velocity measurement values by averaging multiple measurements taken during the day for all offices discussed in our present study. The ambient air velocity ranged from 0.19 to $0.21 \mathrm{~m} / \mathrm{s}$ according to the data in the Figure 7.

On the basis of this study, thermal comfort parameters were evaluated for work offices based on the winter months. However, in order to reveal the necessity of similar studies in general and to understand the necessity of improving thermal comfort conditions due to high temperature increases in the summer months for Bingöl province in particular, some average measurement results taken in May, June and July are given in Table 4. Appropriate situation assessments will be made for the four seasons by using the detailed measurement results to be obtained in later studies. Considering the average temperature values for May, June and July in Table 4, the average temperature values in May were $26^{\circ} \mathrm{C}$, with an increase of approximately $2^{\circ} \mathrm{C}$ for June. Average values for summer season were approximately $29^{\circ} \mathrm{C}$. Judging by the results of July, indoor temperature values increased by $4{ }^{\circ} \mathrm{C}$ compared to June and took an average value of $33^{\circ} \mathrm{C}$. Considering that the indoor and outdoor temperature difference varies approximately between $7 \sim 10^{\circ} \mathrm{C}$. It can be concluded that the outside temperature will be approximately $42{ }^{\circ} \mathrm{C}$. As a matter of fact, it has been understood that the average external temperature value in Bingöl province in July is 40. It is understood from the same table that the relative humidity values for all three months are also below the standards. 


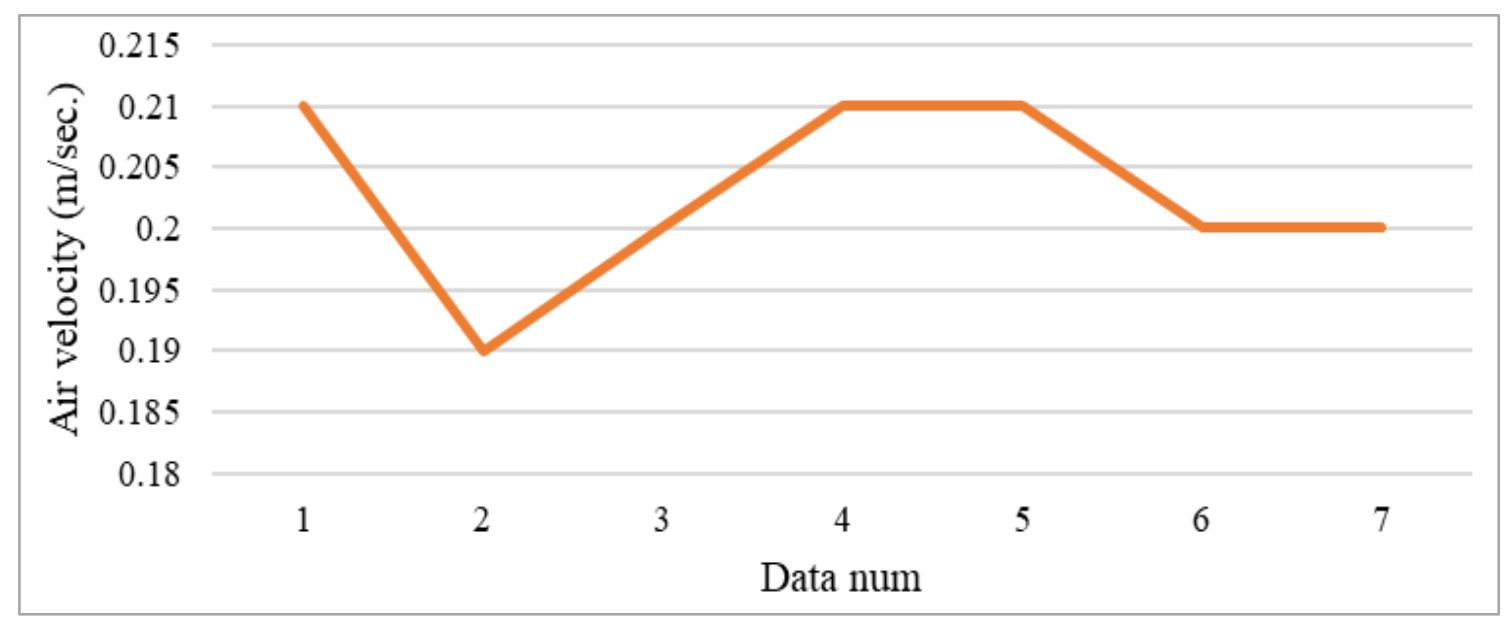

Figure 7. Ambient air velocity

Table 4. Average values of May, June and July

\begin{tabular}{|c|c|c|c|}
\hline Direction of offices & \multicolumn{2}{|c|}{ May } & Dew point $\left.{ }^{\circ} \mathbf{C}\right)$ \\
\hline NE & Temp $\left({ }^{\circ} \mathbf{C}\right)$ & 25,4 & 4,4 \\
\hline Middle Offices & 25,9 & 25,4 & 5,3 \\
\hline SW & 26,7 & 21,4 & 2,3 \\
\hline Average & 26,2 & 24,1 & 4,0 \\
\hline & 26,3 & June & 6,0 \\
\hline NE & & 23,5 & 7,3 \\
\hline Middle Offices & 29,0 & 24,3 & 6,6 \\
\hline SW & 29,8 & 24,9 & 6,6 \\
\hline Average & 28,7 & 24,2 & \\
\hline & 29,2 & July & \\
\hline NE & 32,9 & 22,3 & 8,5 \\
\hline Middle Offices & 33,2 & 26,3 & 11,2 \\
\hline SW & 33,0 & 23,7 & 9,5 \\
\hline Average & 33,0 & 24,1 & 9,7 \\
\hline
\end{tabular}

\section{Conclusion}

Thermal comfort conditions were investigated in the Bingöl University Faculty of Engineering and Architecture offices in this study. Offices were evaluated in three categories and mean values were taken in the building directed in the direction of southeast (SE) and northwest (NW). Temperature, humidity, and dew point values of the offices directed to the northeast (NE) (offices 1,2, and 3) were evaluated among themselves, and the related data of the middle offices (offices 4, 5, 6 and 7) were evaluated among themselves and finally related data of Offices facing the South West (SW) (offices 8 and 9) were evaluated among themselves. Monthly mean temperature, humidity and dew point values were obtained. It has been understood that the mean comfort temperature value found in all the offices of the university staff is in compliance with ASHRAE standards and the relative humidity of the air is insufficient. The mean temperature values of January and February were $24.7-25.9^{\circ} \mathrm{C}$, the radiation temperature value was in the range of $22-25^{\circ} \mathrm{C}$ on average, and the relative humidity values were $17.7 \%$ and $24.3 \%$. The ideal thermal comfort temperature should be between $20^{\circ} \mathrm{C}-25.5^{\circ} \mathrm{C}$ and the relative humidity (RH) should be between $30-60 \%$ according to ASHRAE standards. The relative humidity values were far below the limit values (30-60\%) whereas the comfort temperature values were between the standard values for both January and February.

Humidity value increases in hot weather and decreases in cold weather. Accordingly, the amount of relative humidity was lower in the colder month of January. However, it was found that the humidity value in the 
evaluated offices was below the standard for both winter months and also for summer season. Low relative humidity in offices significantly affects the performance of employees. Drying occurs on the nose, eye, mouth, and skin as a result of long-term studies in low humidity environments. However, conditions such as dry cough, pharyngitis, etc. may occur. The body may dehydrate above normal. Water should be consumed frequently and precautions should be taken to avoid the dangers of low humidity in winter in these cases. Air velocity is another comfort parameter also measured, was obtained as the daily mean air velocity. The mean velocity value was in the range of $0.18-0.21 \mathrm{~m} / \mathrm{s}$ and it was in the standard according to the values found for seven days.

In order to give an idea about the necessity of investigating the thermal comfort parameters for the summer months, the averages of some data from May, June and July were evaluated. In this respect, it is obvious that there is a need for comprehensive studies to improve thermal comfort parameters in order to protect the health status of those using the existing spaces and increase their productivity. In this regard, we hope to work on what can be done to improve the thermal comfort conditions in these places in our future studies.

\section{Acknowledgements}

This research is supported by the Bingöl University, Scientific Research Project Fund

(BAP-MMF.2020.00.004).

\section{REFERENCES}

[1] Klepeis, N. E., Nelson, W. C., Ott, W. R., Robinson, J. P., Tsang, A. M., Switzer, P., . . . Engelmann, W. H., "The National Human Activity Pattern Survey (NHAPS): a resource for assessing exposure to environmental pollutants". Journal of Exposure Science and Environmental Epidemiology, vol. 11, no. 3, pp. 231-252, 2001. DOI:10.1038/sj.jea.7500165

[2] Awada, M., et al., "Ten questions concerning occupant health in buildings during normal operations and extreme events including the COVID-19 pandemic". Building and Environment, vol. 188, no.107480, pp. 1-11 2021. DOI: 10.1016/j.buildenv.2020.107480.

[3] Humphreys, M.A., J.F. Nicol, and I.A. Raja, "Field studies of indoor thermal comfort and the progress of the adaptive approach". Advances in building energy research, vol. 1, no. 1 pp. $55-88$, 2007. DOI: 10.1080/17512549.2007.96872 69.

[4] Rincón-Martínez, J., et al., Methodological Proposal to Develop Adaptive Thermal Comfort Studies Under Lab Controlled Conditions. Civil Engineering and Architecture, vol. 8 no.6 p. 1202-1216, 2020. DOI: 10.13189/cea.2020.080605
[5] Altomonte, S., Schiavon, S., Kent, M. G., \& Brager, G., "Indoor environmental quality and occupant satisfaction in green-certified buildings". Building Research \& Information, vol.47, no.3, pp. 255-274, 2019. DOI:10.1080/09613218.2018.1383715.

[6] Ortiz, M.A., S.R. Kurvers, and P.M. Bluyssen, "A review of comfort, health, and energy use: Understanding daily energy use and wellbeing for the development of a new approach to study comfort”. Energy and Buildings, vol. 152, pp. 323-335, 2017.DOI: 10.1016/j.enbuild.2017.07.060.

[7] Wargocki, P. and D.P. Wyon, "Ten questions concerning thermal and indoor air quality effects on the performance of office work and schoolwork". Building and Environment, vol.112, pp. 359-366, 2017. DOI: 10.1016/j.buildenv.2016. 11.020 .

[8] Zhao, W., Kilpeläinen, S., Kosonen, R., Jokisalo, J., Lestinen, S., Wu, Y., \& Mustakallio, P., "Human response to thermal environment and perceived air quality in an office with individually controlled convective and radiant cooling systems". Building and Environment, vol. 195, pp. 107736, 2021. DOI: 10.1016/j.buildenv.2021.107736.

[9] ASHRAE-Handbook, "Physiological Principles: Comfort and Health", 1989.

[10] ASHRAE-Standart-55, "Thermal Environmental Conditions for Human Occupancy(ANSI Approved)". Atlanta: American Society of Heating, Refrigerating, and Air-Conditioning Engineers (ASHRAE), 2013.

[11] Choi, J.-H. and D. Yeom, "Development of the data-driven thermal satisfaction prediction model as a function of human physiological responses in a built environment". Building and environment, vol.150, pp. 206-218, 2019. DOI: 10.1016/j.buildenv.2019.01.007.

[12] Olgyay, V., "Design With Climate: Bioclimatic Approach to Architectural Regionalism", New Jersey: Princeton university press, 1969 , pp. 2-100.

[13] Fanger, P.O., "Thermal comfort. Analysis and applications in environmental engineering. Thermal comfort". Analysis and applications in environmental engineering., 1970, pp. $1-244$.

[14] Szokolay, S., "Introduction to Architectural science the basis of sustainable design”, Linacre House, Jordan Hill. Oxford, 2004. pp. 7-13.

[15] Yamankaradeniz, R., Horuz, İ., Coşkun, S., Kaynaklı, Ö., \& Yamankaradeniz, N., "İklimlendirme esasları ve uygulamaları (Air conditioning: principles and applications)". İstanbul: Dora Yayıncıllk. 2015, pp. 1-626.

[16] De Oliveira, C.C., R.F. Rupp, and E. Ghisi. "Influence of Air Movement and Air Humidity on Thermal Comfort in Office Buildings in Florianópolis, Brazil”. 35th PLEA Conference-Sustainable Architecture and urban Design: Planning Post Carbon Cities, University of a Coruña, Spain, Sep. 2020. DOI: 10.17979/spudc.9788497497947.

[17] Lundgren, K., Kuklane, K., Gao, C., \& Holmer, I., "Effects of heat stress on working populations when facing climate change". Industrial health, vol.51, no.1, pp. 3-15, 2013. DOI: $10.2486 /$ indhealth.2012-0089.

[18] Ma, N., Aviv, D., Guo, H., \& Braham, W. W., "Measuring 
the right factors: A review of variables and models for thermal comfort and indoor air quality". Renewable and Sustainable Energy Reviews, vol. 135, pp. 110436, 2021. DOI: 10.1016/j.rser.2020.110436.

[19] Giannopoulou, K., Livada, I., Santamouris, M., Saliari, M., Assimakopoulos, M., \& Caouris, Y., "The influence of air temperature and humidity on human thermal comfort over the greater Athens area". Sustainable Cities and Society, vol.10: pp. 184-194, 2014. DOI: 10.1016/j.scs.2013.09.004.

[20] He, Y., N. Li, and Q. Huang, “A field study on thermal environment and occupant local thermal sensation in offices with cooling ceiling in Zhuhai, China". Energy and Buildings, vol.102, pp. 277-283, 2015. DOI: 10.1016/j.enbuild.2015.05.058.

[21] ISO-7730, "Ergonomics of the thermal environmentassessment of the influence of the thermal environment using subjective judgement scales". ISO: Geneva, Switzerland, 2005.

[22] Zhang, G., Zheng, C., Yang, W., Zhang, Q., \& Moschandreas, D. J., "Thermal comfort investigation of naturally ventilated classrooms in a subtropical region". Indoor and Built Environment, vol.16, no.2, pp. 148-158, 2007. DOI: $10.1177 / 1420326 X 06076792$.

[23] Hisarligil, H., "Exploring the courtyard microclimate through an example of Anatolian Seljuk Architecture: the thirteenth-century Sahabiye Madrassa in Kayseri", in Sustainability in energy and buildings, Springer, . 2013, pp. 59-69.

[24] Amiraslanpour, M., Ghazanfarian, J., Nabaei, H., \& Taleghani, M. H., "Evaluation of laminar airflow heating, ventilation, and air conditioning system for particle dispersion control in operating room including staffs: A non-Boussinesq Lagrangian study". Journal of Building Physics, vol., pp., 2020. DOI: 1744259120932932.

[25] Indraganti, M., Ooka, R., Rijal, H. B., \& Brager, G. S.,
"Adaptive model of thermal comfort for offices in hot and humid climates of India". Building and Environment, vol.74, pp. 39-53, 2014. DOI: 10.1016/j.buildenv.2014.01. 002 .

[26] Manu, S., Shukla, Y., Rawal, R., Thomas, L. E., \& De Dear, R., "Field studies of thermal comfort across multiple climate zones for the subcontinent: India Model for Adaptive Comfort (IMAC)". Building and Environment, vol.98, pp. 55-70, 2016. DOI: 10.1016/j.buildenv.2015.12. 019 .

[27] Rijal, H.B., M.A. Humphreys, and J.F. Nicol, "Towards an adaptive model for thermal comfort in Japanese offices". Building Research \& Information, vol.45, no.7, pp. 717-729, 2017. DOI: $10.1080 / 09613218.2017 .1288450$.

[28] Parsons, K., "Human thermal environments: the effects of hot, moderate, and cold environments on human health, comfort and performance", FL,USA: CRC press, 2002, pp. $1-270$.

[29] Kürüm Varolgüneş, F., Yerel/Vernaküler Mimarinin Sürdürebilirlik Bağlamında Değerlendirilmesi: Geleneksel Bingöl Konutları Örneği (Evaluation of Vernacular Architecture in the Context of Sustanability: The Case of Bingol Traditional Houses). "Journal of International Social Research”, vol.14, no.76, pp.286-300 2021. DOI: 10.17719/jisr.11453.

[30] Dhaka, S., Mathur, J., Brager, G., \& Honnekeri, A. "Assessment of thermal environmental conditions and quantification of thermal adaptation in naturally ventilated buildings in composite climate of India". Building and Environment, vol.86, pp. 17-28, 2015. DOI: 10.1016/j.buildenv.2014.11.024.

[31] Atmaca, I., O. Kaynakli, and A. Yigit, "Effects of radiant temperature on thermal comfort". Building and environment, vol. 42, no.9, pp. 3210-3220, 2007. DOI: 10.1016/j.buildenv.2006.08.009. 